\title{
How scientific is theology really? A matter of credibility
}

\begin{tabular}{|c|c|}
\hline \multicolumn{2}{|l|}{$\begin{array}{l}\text { Author: } \\
\text { Jaco Beyers }{ }^{1,2}\end{array}$} \\
\hline \multicolumn{2}{|c|}{$\begin{array}{l}\text { Affiliations: } \\
\text { 'Department of Biblical and } \\
\text { Religious Studies, Faculty of } \\
\text { Theology, University of } \\
\text { Pretoria, South Africa }\end{array}$} \\
\hline \multicolumn{2}{|c|}{$\begin{array}{l}{ }^{2} \text { Department of Science of } \\
\text { Religion and Missiology, } \\
\text { Faculty of Theology, } \\
\text { University of Pretoria, } \\
\text { South Africa }\end{array}$} \\
\hline \multicolumn{2}{|c|}{$\begin{array}{l}\text { Project leader: J. Beyers } \\
\text { Project number: } 02440237\end{array}$} \\
\hline \multicolumn{2}{|c|}{$\begin{array}{l}\text { This research is part of the } \\
\text { project, 'Religion, Theology } \\
\text { and Education', directed by } \\
\text { Prof. Dr Jaco Beyers, } \\
\text { Programme Manager: Biblical } \\
\text { and Religious Studies and } \\
\text { member of the Department } \\
\text { of Science of Religion and } \\
\text { Missiology, Faculty of } \\
\text { Theology, University of } \\
\text { Pretoria. }\end{array}$} \\
\hline \multicolumn{2}{|c|}{$\begin{array}{l}\text { Corresponding author: } \\
\text { Jaco Beyers, } \\
\text { jaco.beyers@up.ac.za }\end{array}$} \\
\hline $\begin{array}{l}\text { Dates: } \\
\text { Received: } 25 \mathrm{~A} \\
\text { Accepted: } 09 \mathrm{~A} \\
\text { Published: } 28\end{array}$ & $\begin{array}{l}\text { pr. } 2016 \\
\text { Iug. } 2016 \\
\text { Oct. } 2016\end{array}$ \\
\hline \multicolumn{2}{|c|}{$\begin{array}{l}\text { How to cite this article: } \\
\text { Beyers, J., 2016, 'How } \\
\text { scientific is theology really? } \\
\text { A matter of credibility', HTS } \\
\text { Teologiese Studies/ } \\
\text { Theological Studies 72(4), } \\
\text { a3449. http://dx.doi. } \\
\text { org/10.4102/hts.v72i4.3449 }\end{array}$} \\
\hline \multicolumn{2}{|c|}{$\begin{array}{l}\text { Licensee: AOSIS. This work } \\
\text { is licensed under the } \\
\text { Creative Commons } \\
\text { Attribution License. }\end{array}$} \\
\hline \multicolumn{2}{|l|}{ Read online: } \\
\hline 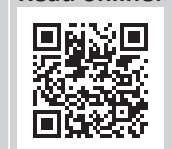 & $\begin{array}{l}\text { Scan this QR } \\
\text { code with your } \\
\text { smart phone or } \\
\text { mobile device } \\
\text { to read online. }\end{array}$ \\
\hline
\end{tabular}

The criteria for what is considered as science have been debated for a very long time. This article assumes the scientific nature of Theology as a given. This article discusses in three concentric circles the scientific nature of Theology and the type of contribution Theology can make. The first circle addresses the nature of science. This broader look at what is considered to be science sets the context for the ensuing discussion. Secondly, Theology as science is investigated. The criteria which make Theology an indispensable part of the scientific project is identified as the ability to collaborate with other sciences based on a shared interest in reality and creation. Further, Theology as science has the ability to contextualise the products of scientific efforts to be relevant not only to the faith community but to society at large. Theology as science requires a critical self-reflection which does not only include a self-understanding but also a self-renewal. The third concentric circle focusses on the scientific nature of Theology as practised at the Faculty of Theology at the University of Pretoria. The Faculty of Theology endeavours to produce life-giving Theology. To prove itself to be scientific Theology needs to act credible by contributing to the wellness of society.

\section{Introduction}

The debate on whether Theology deserves a place among the sciences is an old debate. Over centuries the intensity of the debate ranged between vigorous enmities to subtle suggestions. The main argument is that Theology cannot be considered a real scientific discipline and therefore there is no place for it at a university. The true underlying issue at hand I suspect is the polarity between reason and faith. McGrath (2003:21) alludes to this tension between rationality and faith. Theology is perceived according to modernistic standards to be concerned with matters of faith and does not necessarily subscribe to the general accepted rules of rationality. It can be argued from a postmodern position that Theology is indeed adhering to rationality but on a different level than for instance natural sciences. The metaphor of music applies: there are different categories of music that is, jazz, rock and roll, classical, blues, but still all subscribe to the basic rules of musicology. Musicians recognise when something is music although not all types of music are the same. In similar fashion sciences each have a unique approach and content, although each adheres to acceptable rules of engagement with reality.

If Theology is then considered a science, ${ }^{1}$ what is expected of Theology? This question already assumes the intellectual integrity of Theology. Peterson (2008:564) formulates this question by indicating that the true question is rather what kind of theologising should take place. Munchin (2011a:11) attempts to answer this by stating 'Theology was a necessarily ecclesial and fideistic affair'. Theology provides clarity on matters of faith and serves the faith community. But Theology as science cannot merely have meaning for the initiated few who are already part of a faith community. Then Theology has isolated itself as serving a small segment of society and has become irrelevant to the rest of society. This is one of the biggest challenges for Theology: being deemed as an irrelevant contributor to society.

When Karl Barth in his Church Dogmatics in the opening sentence makes the statement 'Dogmatics is science' he is addressing a longstanding argument. Although the German word used by Barth, Wissenschaft, should rather be interpreted as referring to academic and scholarly, it certainly is in his view to mean science as well. ${ }^{2}$ If Theology is a science, as Pannenberg argues (1973:225), why should we today still agree to this; only because Pannenberg and others (i.e. Barth, Bultmann, McGrath) say so? Theology is a science because it complies with the criteria to be classified as a 1.Pannenberg's work (1973) is devoted to illustrating this. McGrath $(2001,2002,2003)$ also argues this convincingly in his seminal, threevolume work A Scientific Theology.

2.Compare David Munchin's (2011:1) reference to his matter. 
science. If this is taken for granted that Theology is science, what type of science does Theology intent to be? Should we perhaps ask how scientific is Theology as to imply that there are different degrees of being scientific? Or is the scientific character of Theology only in its methodology or also in its content? What is the scientific contribution Theology intends to make? Can Theology still be considered a science under a new paradigm? Does Theology as science transmit and produce knowledge which is indispensable for human existence? Does Theology contribute to a credible awareness of reality? Or as Ritschl (1996:35) formulates the question: does Theology make any new contributions to science?

These are the questions this article wants to address. This is not an attempt at proving Theology to be a science. That is a presupposition in this discussion. Rather at a qualitative level of consideration the question ought to be what type of scientific contribution ought Theology to make. ${ }^{3}$

This article wants to argue that Theology as science has challenges under a post-modern paradigm. ${ }^{4}$ The challenge is however not to prove Theology as science but rather to prove that Theology still contributes indispensable knowledge. This article discusses the way in which Theology acts as science and contributes to the (scientific) community in twenty-first-century South Africa.

The discussion in this article can be presented in three concentric circles: a wide outer circle addresses the nature of science in general; then in a narrower circle a discussion on Theology as science ensues, presenting the criteria for determining the indispensability of theological contributions; and lastly, a narrow inner circle, closer to the essence of this article, focusses on a presentation of the policy of the Faculty of Theology at the University of Pretoria for doing life-giving Theology.

\section{The nature of science}

To discuss the nature of science is to discuss the nature of the universe: firstly, where does one begin and what does one not discuss. What is probably important is to differentiate between science and technology. Not all knowledge can be labelled as scientific. Secondly, there seems to exist a notion to assume that science started in the Near East, developed among the Greeks (Rosenberg 2012:3) and ended up as part of Western civilisation influencing all other cultures (Rosenberg 2012:30).

There however exists the understanding that no other science exist besides what is known as 'Western science' (Rosenberg 2012:31). This however needs to be contested. The status of indigenous knowledge is lately assumed to be of equal value than 'Western science'. Theoretical and practical investigation, analysis and description already existed in early civilisations.

3.In the light of the intent of this article this sentence can be extended to also read ' and does the Faculty of Theology at the University of Pretoria intend to make'.

4.McGrath (2002:191) indicates that postmodernism has with its limitations and flaws necessitated the consideration of a paradigm post-postmodernism. What practising Theology under this new paradigm will look like is still unclear.
Feyerabend (1987:283) questions the superiority of Western science in determining the truth. Knowledge makes sense within its own cultural context. It is for Feyerabend (1987:283) impossible to define science. Feyerabend (1987:280) suggests that science is one among many ways of gaining knowledge. This leads Feyerabend to his renowned statement that the end of rationality as only means of reaching knowledge is due.

Science is preceded by and consists of knowledge. Knowledge as such refers to the ability to notice and interpret phenomenon (Feyerabend 1987:106). The nature of this knowledge however needs to be specified. Is it insights based on magic, religion or science as Frazer would suggest (1993:712)? Magic is based on the order in which ideas present themselves to the human mind, whereas science is based on the 'patient and exact observation of the phenomena' (Frazer 1993:712); magic taking on a subjective interpretation of reality and how to manipulate it and science an objective side of reality and coping with it.

In judging the history of the development of knowledge, Feyerabend (1987:111) states that the oral status of knowledge seems to be growing again; returning to what Plato referred to as the 'living discourse' as the only true form of knowledge. For some (compare Feyerabend 1987:115) stories are better suited to serve the scientific ideas than concepts. Today however knowledge is no longer conveyed in one form. The abundance of vehicles (i.e. art, drama, technology, media) to convey knowledge reduced the narrative to only one form among many. Science no longer is something to be found only in books. ${ }^{5}$

Thomas Kuhn made a huge contribution to understanding the process of creating knowledge. For Kuhn (1962:137) science develops as it passes through the lenses of competing paradigms. The knowledge of earlier times is the result of earlier investigations on similar problems according to similar theories that can still be defined as scientific theories in the light of current investigation. The value and meaning of knowledge can therefore change over time as the paradigm through which knowledge is viewed changes. World views become the macro-paradigms of human existence.

When addressing the nature of science the question to be scrutinised is whether science is the effort at making sense of reality or the creating of reality? A Platonic philosophy will argue that reality only exists in a metaphysical state, whereas an Aristotelian philosophy will argue that matter is to be engaged, analysed and studied, resulting in the natural sciences. As the scope of science rarely changes, the conditions under which science is however practised constantly change, ${ }^{6}$ any science needs to reflect on and test its own results. ${ }^{7}$ Change and revision are always part of the scientific method

5.Feyerabend (1987:109) quotes Plato when discussing the limitations of writing. After the rise of writing it was generally accepted that knowledge was that which one can extract from a written page (Feyerabend 1987:110).

6.Compare in this regard Thomas Kuhn's theory on changing paradigms.

7.This point is taken up later and applied to Theology as self-reflecting science. 
(Munchin 2011a:3). In this way science fulfils both functions of making sense of and simultaneously creating reality. ${ }^{8}$

Science is concerned with understanding. McGrath (2003:135) points out that natural sciences and scientific Theology offers explanations of reality. These explanations serve to explain the way things truly are. ${ }^{9}$ What follows is a short discussion on how science facilitates understanding.

The development of the process of coming to knowledge and understanding has a long history. ${ }^{10}$ When Jürgen Habermas (1968) writes a short history of the ways in which humans come to realisation (Erkenntnis) he ends up discussing various theories of knowledge (Wissen). The concept of a theory of knowledge originated during the nineteenth century. Habermas (1968:11) identifies two main categories of realisation: empirical and rational. The mistake would be to equate epistemology (Erkenntnis) with science (Wissenschaft). Epistemology as philosophical category provides opportunity for the practice of science. For Habermas (1968:11) the theory of realisation (epistemology) is not limited to realisations arrived at through experiential science. ${ }^{11}$ The theory of realisation (epistemology) is not subject to a theory of science.

Thereby Habermas sets the philosophical consideration of the process of acquiring knowledge apart from the understanding of what is considered as science. The discussion of the nature of science is something totally different from a theoretical discussion of whether attaining insight and awareness of reality is possible.

Habermas (1968:11-12) provides a bird's-eye view of the development of how this line of thought developed over time. He starts of by discussing Kant's transcendental-logical questioning of epistemology. Awareness and realisation is part of human consciousness. Kant provides a critical evaluation of whether epistemology is at all humanly possible. For Kant practical knowledge and reflexive judgement is logically part of the process of epistemology. Humans should be aware of themselves in a process of engaging reality.

According to Hegel's critique of Kant's transcendentallogical questioning, philosophy relinquishes and not only changes its position towards science. Habermas draws the conclusion that after Kant, science was no longer taken serious philosophically. Cassirer (1909:10) indicates that this difference between philosophy and science (Wissenschaft) should only be understood in terms of the influence both exercise on one another. Engagement with reality is not the monopoly of one, but the privilege of all approaches in

\footnotetext{
8.It can indeed be argued that scientific activity can result in the creation of theoretical reality obscuring true reality.

9.McGrath (2003:135) emphasises that Theology is not only the attempt at providing scientific explanations but also the attempt at formulating the appropriate response to the revelation of God.

10.Compare Peter Machamer's (2002:1-17) short historic overview of the development of the philosophy of science.

11.The difference between a priori and a posteriori knowledge is relevant here (compare Rosenberg 2012:1).
}

culture (Cassirer 1909:10). This would open up the possibility for a theological engagement with reality as McGrath explains below. After Kant, science became only one of many categories of possible modes of awareness. Scientific knowledge cannot be equated to a specific philosophy. Science is not the only mode of access to reality. Science cannot claim to have the absolute knowledge of reality. In current times the different types of science may be just in such a battle. Compare the differences in African science as opposed to Western understanding of science and the consequent claim that Western science is the only legitimate science (Hountondji 1983:61). The same animosity is experienced when natural sciences claim to be superior in its knowledge of reality, whereas human sciences are seen as too subjective and consequently inferior.

The theory of awareness (Erkenntnis) (epistemology) is since the nineteenth century replaced by the theory of science (Wissenschaft). Habermas (1968:13) judges this change in approach as a shift towards scientism (szientismus). This is the notion that science is no longer considered as only one form of possible awareness (Erkenntnis), but that epistemology (Erkenntnis) is identical to science (Wissenschaft).

With Auguste Comte positivism arrived on the scene (Habermas 1968:13). Through empiricism and rationalism science was now utilised to enforce its results as normative, without reflecting on the results. The basis for science was consolidated through science.

What however is necessary is that any discussion on the conditions for possible awareness of reality must engage with analytical theory of science (Habermas 1968:13). A return to a situation prior to scientism is impossible. A stage of reflexion is necessary. Habermas suggests considering the radical self-critique of an epistemology that Hegel proposed. Hegel as opposed to Kant indicated that the phenomenological self-reflexion on awareness is a necessary radicalisation of the critique on awareness.

Habermas (1968:170) indicates the difference between the Natural and Human sciences as Dilthey identifies it that the Human sciences function within a different methodological frame and allows itself to be guided by a different interest in knowledge (Erkenntnisinteresse) as pragmatism guides natural sciences. Dilthey distinguishes between science as activity for understanding and explaining (Habermas 1968:182). The human sciences are prone to understand and natural sciences to explain. Dilthey makes a separation between Natural and Human sciences. Under Human sciences (Geisteswissenschaft) he lists (1957:79-81) disciplines such as history, economy, justice, political sciences, science of religion, literature and poetry, art and music, philosophy and psychology.

It is not only the interest in different objects that differentiates the two types of sciences. As example, Dilthey mentions psychology which is interested in human behaviour but still functions as a natural science. The difference between the 
two sciences lies for Dilthey (1957:248) in the way of engagement of the researching subject with the object. The natural sciences engage with a reality which is governed by general laws which exclude the researching subject. Natural sciences study these laws governing the natural world (Dilthey 1957:82). Although humans are part of the reality governed by laws, by studying the laws, humans are excluding themselves, setting themselves apart from such reality and thereby become the centre of such reality (Dilthey 1957:82).

In an attempt at a social theory Freud reduces human action in society to two activities: science and technique (Habermas 1968:337). Through technical ability humans are able to manipulate and utilise nature to such an extent to through labour create objects to sell. In such a way society functions as producer. In order to refine technique and production, humans turn to their inner self in search of knowledge to be utilised in labour. This self-reflection is the activity of science. Human existence is then reduced to thinking or reflecting and acting or producing or as Van Niekerk (2011:3) refers to it: labour and communication based on technical and practical abilities. Practising science becomes a natural human activity.

Humans however do not act alone in this scientific endeavour. Nola (2008:263) refers to the social construction of scientific interest. All science is subject to social formation. Knowledge is not only the result of the subject engaging with the object. The tradition and knowledge of the past transferred from generation to the next influences understanding. Science is a collective activity where all engage the same reality and produce unique knowledge that can contribute to a fuller understanding, depending on sciences entering in dialogue.

\section{Theology as science}

When considering the nature of sciences and placing Theology among them, McGrath (2001:8) foresees the relation between Theology and the natural sciences as one of dialogue. When analysing the scientific nature of Theology two different perspectives emanate as dialogue partners: that of the insider, most probably defending Theology and that of the outsider which can be in defence or in opposition to Theology. In the discussion that follows, representatives of these two perspectives are presented. Natural sciences do not prove or disprove Christianity but can serve as guiding light, supporting theological reflection in terms of assumptions and methodology (McGrath 2001:7). It is clear that McGrath understands the relationship between Theology and science not as in opposition nor as identical but as collaborative. This implies that Theology can indeed take up its rightful place among the sciences.

Pannenberg (1973:12226) indicates how Theology was for the first time considered a science during the thirteenth century under the influence of the church father Augustine. Before the time of Augustine Christian teaching was considered to be sapientia (wisdom) and not scientia (science). Science had to do with temporal things while wisdom was concerned with the eternal things such as God. Science, Augustine argued, does not exclude wisdom; science can lead to wisdom (Pannenberg 1973:13). Science had to serve wisdom. The true philosophy for Augustine was Christian doctrine. Since the thirteenth century theological wisdom was considered a science in the sense Aristotle described science (Pannenberg 1973:226). Ford (2011:1) still today considers the goal of Theology to search for wisdom. With wisdom Ford (2011:1) means the connection of understanding with practice and the engagement with the whole of life. What the wisdom Theology seeks is to provide an appropriate response to the cries for 'love, food, peace, security, freedom, health, hope, truth, joy and God', cries we still hear today (Ford 2011:3).

Thomas of Aquina tried to define Theology as deduced (abgeleitete) science (Pannenberg 1973:228). Based on Aristotle's system the principles of deduced sciences was not contained in such sciences self but in a superior overarching science. Thomas understood the wisdom of God to be the overarching science from which Theology is deduced. The credo of faith was expression of the wisdom of God and also provided the authority for Theology as science. The close relationship between Theology and faith is obvious here.

Pannenberg identifies the different definitions of science applied to Theology over time: speculative and theoretical science, practical science (1973:230) and positivistic science (1973:240). Schleiermacher differentiated between historical Theology, philosophical Theology and practical Theology which is concerned with practical guidelines on being church (Pannenberg 1973:252).

Theology is not different from any other attempt at practising science. McGrath (2001:133) provides insight into this when he argues that reality as viewed by natural sciences is the same reality Christians view as creation and try and discern through Theology (McGrath 2002:245, 295). Understanding nature rationally, as science attempts, is similar in the way Christianity attempts to explain creation rationally. ${ }^{12}$ Reality, nature, is what Christians understand as creation, created by God (McGrath 2001:193). Reflecting on creation needs reflection on the One who created all -'Christian understanding of creation leads directly to the conclusion that there is a correspondence ... between the works of God and the being of God' (McGrath 2001:193). Theology is the human attempt to grasp something of the rationality of the created order (McGrath 2001:193, 2002:248) or Theology has the goal to link the beliefs and practices of the Christian community to contemporary experience of Christians (McGrath 2002:295). This important point is taken up later on when discussing the relevance of Theology.

McGrath (2002:245) is however clear that natural science and Theology, although both reflect on their encounter with reality, are not identical in content and method. Further McGrath (2002:245) emphasises as a point of extreme 12.This argument of McGrath is based on an argument of Polkinghorne (Cf. McGrath 2001:197) 
importance that engagement with reality implies that each 'stratum of reality' be engaged 'according to its distinct nature'. This implies that each science has to adhere to the rules applying to the nature of reality under investigation. In this engagement McGrath (2003:82) points out that engaging reality appeals to human rationality. All sciences are engaged with the real world. ${ }^{13}$ Reality is stratified and each requires a unique mode of investigation (McGrath 2003:82). McGrath (2002:247) identifies the reality Theology is concerned with as a reality independent of the human recognition and therefore requires a unique methodology not to be confused with other disciplines. This makes clear that Theology is science (content) and also relates to the scientific nature of Theology (methodology).

Theology experienced an unprecedented explosion during the twentieth century. The reasons for this Ford (2011:7) identifies are the fact that Christianity and education spread globally. Knowledge was disseminated at an extreme pace resulting in the epithet for the end of the twentieth century of 'information era'. All over the world new theologians started dialoguing with the traditional strong theological traditions coming from Europe. This caused the voices of Christians all over the world to be heard in new ways. The new ways include, according to Ford (2011:8), that of postmodern theologies such as Theology and race, biology, social sciences, literature, art, music, film, spirituality and feminism. All these conversations Ford says need to be taken further. Part of the expansion of Theology is contributed by the newly found confidence of ecumenical partners from all over the world (Ford 2011:9). Theology was enriched with the sharing of varied views and interpretations. Theologies from different parts of the world started specialising in specific areas: liberation, environmental issues, politics, economics, ideology (Ford 2011:10). Ford (2011:11) highlights four specific new developments in Theology: Theology and poetry, Theology and the sciences, Theology and the public life and Theology and the religions. Theology has proved itself as a productive partner in science. But how scientific is Theology? A short discussion of the history and arguments in the controversy as to Theology's scientific nature follows.

Munchin's research (2011a and 2011b) reveals part of the history of the theological controversy. When Barth is confronted by Scholz questioning the scientific nature of Theology, Barth decides not to partake in the debate. Barth indicated that Scholz's prerequisites for Theology to be considered a science are unacceptable (Pannenberg 1973:272).

In the debate between Barth and Scholz on the scientific character of Theology, Scholz sets three criteria for Theology to be classified as science (Pannenberg 1973:271-272): (1) Propositions or theories or hypothesis (Sätze), (2) coherence (Kohärenz) and (3) controllability (Kontrollierbarkeit). (1) In science there is only room for definitions, questions and hypothesis. Hypotheses are statements of which the truth is

13.The metaphor used in the Introduction of music applies here. As all musicians know the rules of playing music, there still exist different types of music. All sciences are engaged with the same reality, although reality is stratified. suspected but still needs to be confirmed. All hypotheses, especially opposing hypotheses, cannot co-exist, otherwise the border between fact and fiction disappears. (2) Hypotheses need to refer to only one field. A body of knowledge can only be considered to belong to one science when the hypotheses refer to the same subject. Some coherency is required. (3) The truth of theological statements needs to be tested. Verification is according to Scholz impossible within Theology (Pannenberg 1973:272)..$^{14}$ A reader of Theology needs to be able to judge for themselves if hypotheses in Theology are correct. Scholz's conclusion is that Theology is not science as it does not comply with these requirements. At most Theology is a mundane effort at testing personal belief convictions.

In spite of the objections by Scholz, Barth maintained the scientific character of Theology (Pannenberg 1973:273). Barth however could not allay the concerns of Scholz, ending with a vague answer as to the true object of Theology as science (Munchin 2011b:2). For Scholz the problem remained that Theology cannot state hypotheses and claim they are true since Theology interprets faith as a radical risk. Theology still adheres to naturalistic and positivistic schema as to what science is (Munchin 2011b:441). A risk cannot be tested as to its being true or not. Barth maintained that Theology is faithscience (Glaubenswissenschaft) (Pannenberg 1973:273).

T.F. Torrance, a student of Barth, however takes up the challenge set by Scholz when years later similar accusations are made by Peter Feyerabend, who was a student of Karl Popper. Feyerabend is attacking the positivistic conceptions of science and the foundationalism and intend to deconstruct objectivity professed by Theology (Munchin 2011a:7). Feyerabend (in Munchin 2011b:442) argued that there is no such thing as scientific method and objected to rationality, objectivity and truth, describing himself as an 'epistemological anarchist'. Needless to say that not many took Feyerabend serious (Munchin 2011b:442). Torrance's response is to maintain the scientific character of Theology through his view that science is based on revised understanding of objectivity. Torrance claims that objectivity is immune to deconstruction. Torrance draws a parallel between Theology and natural science to illustrate Theology is indeed a science: 'For Torrance the biblical material is analogous to the data of natural science, the revelation is analogous to discovery and dogmatic Theology is the theoretical and systematising reflection on that data' (Munchin 2011b:447). The outcome of the argument is that Torrance succeeds in maintaining the scientific character of Theology (Munchin 2011a:8, 2011b:450, 455).

The object of Theology's scientific endeavour is God. But for Torrance (in Munchin 2011a:8) God is the Creator, Redeemer and Sustainer of the universe (natural world). For Torrance the universe is incomprehensible without God. The object is thus not only God, but the Creator of the natural world, thus creating a connection between Theology as human science and natural science. In this way Theology contributes to an understanding of the natural world. As pointed out earlier, 14.Compare Munchin's (2011) account of the debate between Barth and Scholz. 
this is also the argument McGrath uses to indicate the correlation between natural science and Theology.

Bultmann's (1984:45) description of what constitutes science still reflects a modernistic understanding of subject as set up against object. Science is by its very nature objectifying. Bultmann acknowledges the fact that science as objectifying process is a modernistic problem. The modern assumption is that the object remains static and is not changed by research or observation by the scientist. Science is the effort to illuminate objects to which we as humans have access through our existence. The methods required to illuminate is determined by the object self. The purpose of science, Bultmann (1984:46) indicates, is for the sake of knowing.

Although science is in itself without value judgement, Bultmann (1984:46) assigns several values to the way in which science is conducted: the object is seen for what it is and not in terms of the impression it makes. The object is investigated as to understand it as it presents itself in relation to its environment. Science is reason, science describes. Science is not interested in discovering the use of objects, as if science has a utilitarian concern. ${ }^{15}$ The object in terms of its relation with the whole should be considered and not only in terms of its relation with the scientist.

Bultmann (1984:50) indicates that the traditional object of Theology's scientific endeavour is God. God however cannot be objectified. Is the object of Theology as science then faith (Bultmann 1984:51)? The result would then be that the object of faith is inaccessible to scientific research. With a distinction between fides qua creditur (the act of believing) and fides quae creditur (what is believed in), Bultmann (1984:52) is trying to indicate that Christian faith consists of the fides qua creditur only in relation to the fides quae creditur. The result then is that the object of that which is believed in must be understood as part of what faith is. This leads Bultmann (1984:52) to the conclusion that the object of Theology is God as the object of faith, as the fides quae creditur. God cannot be grasped through scientific activities unless the nature of faith is also understood (Bultmann 1984:54). The object of Theology is faith in unity with what it believes in. Thus, we can only know God in as far as we believe (faith) we know Him. Faith is encountering the revelation of God in Jesus Christ. Theology is interpreting the content of such meeting (Van Niekerk 2011:6). God makes himself known to humans through his revelation. Humans react with faith, believing that the revelation reveals God.

Pannenberg $(1973: 266,299)$ identifies the object of Theology as the reality of God in his revelation. To have a discussion of God results in dogmatic statements. This is for Pannenberg (1973:301) to be captured in the positivism of subjective faith. God as problem should be the theme in order to overcome positivism. Otherwise faith ends up as an engagement with dogma and doctrine. Van Niekerk (2011:3) refines the object of Theology's attention by indicating that the object of

15.This questions the relevance of Theology if relevance only implies usefulness. Theology does not only provide in some need of society. The result of scientific Theology can
include reaching meaning and understanding without answering to some utilitarian include reaching
Theology is God's revelation in Jesus Christ as witnessed in Holy Scripture and accessed through faith. One attains knowledge in Theology by way of 'hermeneutical understanding'; interpretation mediated by faith, which makes Theology as science different from other sciences (Van Niekerk 2011:3).

Theology is thus engaged with: (1) God, (2) the message of God and (3) ourselves as interpreters of the message (Van Niekerk 2011:7). Theology interprets the symbolism in the message received from God (Van Niekerk 2011:6). The problem is that when God is studied, a certain subjectivism appears. God is however not an object (Bultmann 1984:53). God is part of the metaphysical reality humans try to understand. Our understanding of God results in faith. Faith is a subjective human response, a response out of obedience, according to Barth (Pannenberg 1973:274). These responses in faith cannot be verified as being true or untrue. This however does not relegate Theology to the domain of nonscience. Science engages not only with that which is possible to engage with through the senses. Positivism is not a requirement for science. The apparent subjectivity of the theologian becomes objective when the traditions of transmittance of theological thought through history also becomes the focus of Theology (Pannenberg 1973:279). The argument of collective effort of science as socially determined referred to earlier applies here.

Theology as science is not only limited to the study of God in his revelation, as Ebeling (in Pannenberg 1973:281) points out, but also as God reveals himself in a historic context. The statements made about God over centuries of studying God and his revelation becomes part of the object at which the attention of Theology is directed. What others have said before us, can scientifically be analysed. The horizon of the past, present and future comes into focus through the lens of the revelation of God and how it is interpreted. In this way Theology still makes and continues to make a (scientific) contribution. Compare in this regard Pannenberg's (1973:286) own attempt at applying the hermeneutics of Gadamer of reconciling the horizons of understanding of the author and the interpreter. In every new future horizon the message needs to again be interpreted to reconcile it with the new horizon. Creating a connection between the past and the present is the unending (scientific) task of Theology.

\section{Life-giving Theology}

For a century the Faculty of Theology at the University of Pretoria has participated in this task of Theology of reflecting on statements about God in relation to humans and relating it to our current context. The future lies ahead. How will the Faculty of Theology address a new context filled with new challenges? The Faculty of Theology at the University of Pretoria has formulated its task as follows (Faculty Plan 2015):

Vision: To be a faculty recognised for its creative engagement with life-giving Theology and religious insight, of service to academia, church and community. 
Mission: To achieve this, we commit ourselves to -

Providing relevant theological and religious education;

Nurturing transformative leaders;

Quality research;

Promoting justice, peace, the integrity of creation and a reconciling diversity; and

Engaging people on the margins of society.

Based on this vision and mission, the Faculty formulated as Faculty Research Theme (FRT) the topic of Oikodome building up society to experience life in its fullness. In this way Theology is envisaging its contribution to science as not only relevant to the scholarly community but as transformative to the whole of society.

The test for true Theology according to Ford (2011:3) is whether Theology provides a wise answer to the cries for help in our own context. New contexts require a new search for answers. The wrestling for answers of Theology is not only a wrestle with God but with reality as well (Ford 2011:3). Theological wisdom for Ford (2011:4) lies in the ability to relate all reality (personal and social life; the whole of creation) to God and God's purposes. This requires creative thinking as well as relevant and credible answers in every new context. That is the challenge to Theology. The Faculty of Theology believes by investigating the FRT of Oikodome relevant answers to a contextual question can be provided. To be a credible contributor to society Theology needs to serve society, while still remaining a science and produce knowledge.

Van Niekerk (2011:9) indicates the 'directive interests' of Theology as the result of the interpreting activity as having results for one's own faith as well as the church, the community who receive knowledge from the interpretation of the Holy Scriptures. Theology therefore has a purpose: it produces knowledge for the believer and it provides doctrinal guidance to the faith-community and knowledge on how to minister the gospel to the world. Theology therefore has a dual function: heuristic and utilitarian. It can best fulfil this task if it delivers credible results. Credibility should entail integrity as well as relevance. The results Theology provides need to lie on the continuum of theological endeavours of the past, but it also needs to address the needs of the present context appropriately in order to be considered credible.

Over time several efforts were made to reflect on the scientific nature of Theology. Pannenberg (1973) and more recently McGrath (2001, 2002, 2003) have provided an extensive overview of the historical development of thought on this matter. In his seminal research project called A scientific Theology, Alystair McGrath engaged with discussing Theology as science. For McGrath Theology is the science reflecting on the God who is considered to be the Creator of the natural world on which natural sciences focus their activities. McGrath envisages the complementarity of the two sciences. Theology, when describing reality, must allow itself to be informed by natural sciences. Both Theology and natural sciences have their own methods in approaching reality. According to McGrath both Theology and the natural sciences are a response to reality. Both must proceed a posteriori - that is from observations (i.e. of revealed or natural data respectively) to dogmas. Both must constantly assess and reflect on their results. Dogmas are not to be mistaken for being reality.

What is clear from this most recent description of the relationship between Theology and natural sciences is McGrath's (2001:8) insistence on dialogue between the two parties. The relationship is no longer that of opposition but that of collaborative sciences.

Both natural sciences and Theology by focusing on reality (nature and creation) emphasise the importance to consider the way in which Theology can contribute to and transform the whole inhabited world. Oikodome becomes a way of demonstrating the concern for the wellness of the whole created reality.

A way forward for Theology is indicated by Ritschl. Ritschl (1996:35) is very adamant that if Theology is to survive as science in the new millennium it is to make new contributions to science. He however differentiates between progress (Fortschritt) and new (Neues). Theology is indeed making progress. New methods and applications are found regularly, but Theology rarely comes up with something totally new (Ritschl 1996:36). The achievements by the different disciplines in Theology, Ritschl ascribes to non-theological work. Methods, questions, deductions and criteria implemented in subjects such as Church history and Old and New Testament Studies are not theological of nature. Many products in these disciplines are merely repetition of clichés (Ritschl 1996:36). The conclusion Ritschl (1996:37) arrives at is that Theology seems not to be a science any more. At most Theology can be considered wisdom utilising scientific methods. This argument is countered by arguments by Pannenberg and Torrance indicating that Theology remains a science.

As to the function of Theology, Ritschl (1996:39) suggests that Theology creates language for the implicit obscured concepts hidden from the view of ordinary believers. Theology assists and contributes to the faith experiences of believers. Ritschl (1996:40) refers to this as the therapeutic help to the church by Theology. Ritschl however steps into the utilitarian trap by focussing on the function of Theology instead of the nature of Theology.

Theology not only needs to re-invent or re-introduce the old, it even does not need to try and add on to the old, or interpret the old in terms of the new (Ritschl 1996:43). Theology needs to create something new. Theologians caught in a typical rut think the truth has been established; only the application can be interpreted new (Ritschl 1996:43). Rather Theology needs to consider the reasons, the conditions and the context under which theological statements were made in the past. The relations between past, present and future need to be 
rediscovered (Ritschl 1996:44). Ford (2011:7) indicates how Theology inherits wisdom; riches from the past but cannot merely repeat them. Wisdom of the past must be reformulated in creative (new) ways for the future. Only then can Theology make an indispensable contribution. Not only serving the science community, but society at large. The road forward is set clear: Theology needs to interpret the past anew for the future, in a scientific way.

With the emergence of new ways of theological thought in the twenty-first century, Ford (2011:12) asks to the quality of the theological thoughts arising. What are the criteria for determining creative, indispensable and credible Theology? Ford (2011:13) identifies several criteria to determine the value of Theology's contribution to society.

Back to the sources. Ford (2011:13) uses the French word ressourcement to describe the action of returning to the sources in order to glean from the past what is necessary to nourish Theology and life in the present. As exponents of this position Ford refers to the French theologian Henri de Lubac (cf Ford 2011:13) and Hans Urs von Balthasar (cf. Ford 2011:14). The engagement with the past is not merely a recollection of the past but a creative uncovering of what might have been lost and has meaning for the present. It is insightful that the first requirement for creative, indispensable and credible Theology in the twenty-first century resounds one of the calls during the Reformation: ad fontes! - Back to the roots. The source of Theology being the Scripture, the Word of God where his revelation has been recorded, is to where Theology must turn for normative wisdom.

Engaging with the present. The focussing on the past and present is for Ford (2011:15) essential to Theology. The priority of engagement with the present is engaging with God. The sole focus of Theology is God (also Pannenberg 1973:301). Theology needs to respond to the realities of the world by creatively connecting the secular and religious realities of our world (Ford 2011:17). McGrath (2002:295) has identified the goal of Theology to connect the beliefs and practices of the Christian community of the past with the contemporary communities. Only thus can Theology prove itself to be relevant. Theology is not only a reflection on the past, but meant to have a transformative impact on the present. In this way Theology is indeed participating in explaining and creating reality and thus providing meaningful life.

Truly creative thinking. Ford (2011:17) indicates that the test for true indispensable Theology would be to make a unique contribution to theological thought. He suggests the thought process of abduction as appropriate method of engaging with innovative ideas. Abduction is the imaginative way of conceiving new possibilities and relations between ideas (Ford 2011:18). The way in which human and divine freedom relate creates new possibilities. Bringing Theology into new dialogue with other disciplines (compare Munchin 2011a:3), cultures and religions, events and experiences are all part of making new connections (Ford 2011:19).
Van Niekerk (2011:9) alludes to the new fresh relations Theology should create when he identifies the 'directive interests' of Theology. If Theology wants to remain a relevant science it should produce results serving the faith of the individual as well as the church and the community who receives interpretation of the Holy Scriptures. The purpose of Theology therefore is to produce knowledge for the believer and provide doctrinal guidance to the faith-community and knowledge on how to minister the gospel to the world. Through knowledge of the gospel people experience the lifegiving metamorphosis faith brings about. People filled with faith live differently in the world, now focussing on spreading the life-giving grace of God. Only then does Theology give life in more than one way.

As final criteria, Ford sets forth (2011:20) that theological thoughts are well disseminated. Theology only impacts the lives of people when they read and understand it. Theologians should write in such a way that they are understood.

One of Feyerabend's criticism against Theology as science was that Theology tends to be too theoretical (Munchin 2011b:450). The church became the place protecting the theories. Anyone objecting or questioning the 'theories' would be lambasted by the church. If Ford is taken seriously, Theology should be transparent enough to state what it means and be prepared to defend or change its statements if it is not understood due to ill-formulation. Theology should reflect on itself.

Reflection: self-understanding and self-renewal. As fifth requirement I would like to add the scientific function of Theology to reflect on itself. Creating new theological ideas require reflecting on existing ideas. Reflecting on ideas one subscribe to or not leads to self-understanding. By identifying reasons why one continue or stop to subscribe to certain theological ideas is creating identity. By restructuring one's theological arsenal one is in the process of theologically renewing one's identity. Theology continuously needs to reinvent itself. This reinvention consists of discarding irrelevant theological ideas and finding more appropriate ideas fitting for a new context. Munchin (2011:3) reiterates this by indicating the constant revision which is part of scientific method. In a sense Ford (2011:13) also alludes to this function of Theology by indicating the return to the sources. Theology needs to measure itself continuously by testing its being true to the One whom it is reflecting on.

Reflection is a form of verification. By constantly re-assessing the self the opportunity is there to monitor, correct and adjust. Although self-assessment is without the external input from others it still demonstrates the willingness to stand corrected. An attitude of being willing to be assessed is part of being credible.

\section{Conclusion}

Theology as science seems to have a growing responsibility in a postmodern age on two fronts: that of excessive knowledge which is not necessarily all scientific knowledge 
and on the other side the 'cultural adversaries' as Weinberg calls them (in Pannenberg 2002) who relativises the truth claims of scientific theories. Weinberg (in Pannenberg 2002) refers here to the religious fundamentalists who based on the instant and constant growth of knowledge available on the Internet claim to be the only ones that know the truth. Theology is needed to act as guardian and filter of theological knowledge. In this way Theology produces indispensable knowledge serving society. Some might interpret this as Theology protecting its own domain.

Theology however needs to add a credible voice to any religious debate. The voice of Theology is credible, as it is scientific. This has been reiterated by arguments by Pannenberg, Torrance, McGrath and Ford. It is no longer a question as to the scientific nature of Theology, but much rather a question as to indicate the credible contribution Theology does make to current contexts. This has been successfully argued in this article.

The object for discussion in Theology should always be the problem of God (see Pannenberg 1973:301). Moltmann (2008:31) states that God should always be the centre of theological discussion. The meaning of human existence should be measured in terms of the reality of God. God is the centre of all existence and determines a reality that really matters. This challenges the statements made by untheological worldviews suggesting divergent earthly interests as worthy of pursuing. Theology can then produce a credible answer based on credible reflection on God and human interaction in our own times.

The Faculty of Theology at the University of Pretoria has selected as theme for its centenary celebrations in 2017 'Opening the Gates ...'. The principles underlying this theme are tolerance, resilience, inclusivity and openendedness. This reflects an understanding of a postfoundational Theology, open for dialogue with other sciences and open to conversation with reality, willing to attempt answers to the challenges faced by academics, individual believers and faith communities, facilitating through Theology, life in its fullest.

\section{Acknowledgements Competing interests}

The author declares that he has no financial or personal relationships which may have inappropriately influenced him in writing this article.

\section{References}

Bultmann, R., 1984, 'Theology as science (1941)', in S.M. Ogden (eds.), New Testament and Mythology: And other basic writings, transl. S.M. Ogden, pp. 45-68, SCM Press, London.

Cassirer, E., 1974 [1909], Das Erkenntnisproblem: In der Philosophie und Wissenschaft der neueren Zeit, Band I. Wissenschaftliche Buchgesellschaft, Darmstadt.

Dilthey, W. 1957, Gesammelte Schriften Band VII: Der Aufbau der geschichtlichen Welt in den Geisteswissenschaften, Teubner, Leipzig.

Feyerabend, P., 1987, Farewell to reason, Verso Press, London.

Ford, D.F., 2011, The future of Christian theology, Wiley-Blackwell, Sussex.

Frazer, J., 1993, The Golden Bough: A study in magic and religion, Wordsworth Reference, London.

Habermas, J., 1968, Erkennrnis und Interesse, Suhrkamp Verlag, Frankfurt am Main.

Hountondji, P.J., 1983, African philosophy, myth and reality, Hutchinson \& Co. Publishing, London.

Kuhn, T., 1962, The structure of scientific revolutions, University Press of Chicago, Chicago, IL.

Machamer, P., 2002, 'A brief historical introduction to the philosophy of science', in P. Machamer \& M. Silberstein (eds.), The Blackwell guide to the philosophy of science, pp. 1-17, Blackwell Publishers, Oxford.

McGrath, A.E., 2001, A scientific theology: Nature, vol. 1, William Eerdmans, Grand Rapids, Mi.

McGrath, A.E., 2002, A scientific theology: Reality, vol. 2, William Eerdmans, Grand Rapids, MI.

McGrath, A.E., 2003, A scientific theology: Theory, vol. 3, William Eerdmans, Grand Rapids, MI.

Moltmann, J., 2008, 'What is Christian theology?', Theological Review 29, 31-44.

Munchin, D., 2011a, Is theology a science? The nature of the scientific enterprise in the scientific theology of Thomas Forsyth Torrance and the anarchic epistemology of Paul Feyerabend, Brill, Leiden.

Munchin, D., 2011b, 'Is theology a science? Paul Feyerabend's anarchic epistemology Theology 64(4), 439-455. http://dx.doi.org/10.1017/S003693061100024X

Nola, R., 2008, 'Social studies of science', in S. Psillos \& M. Curd (eds.), The Routledge companion to philosophy of science, pp. 259-268, Routledge, London.

Pannenberg, W., 1973, Wissenschaftstheorie und theology, Suhrkamp Verlag, Frankfurt am Main.

Pannenberg, W., 2002, Facing up: Science and its cultural adversaries, viewed 13 November 2014, from http://www.firstthings.com/article/2002/08/facing-upscience-and-its-cultural-adversaries

Peterson, G.R., 2008, 'Theology, the university, metaphysics and respectability: In praise of folly? Theology and the university', Zygon 43(3), 563-577. http://dx.doi. org/10.1111/j.1467-9744.2008.00939.x

Ritschl, D., 1996, 'Gibt es in der Theologie “Neues”?', in C. Krieg, T. Kucharz \& M. Volf (eds.), Die Theologie auf dem Weg in das dritte Jahrtausend: Festschrift für Jürgen Moltmann zum 70. Geburtstag, pp. 35-45, Gütersloher Verlagshaus, Gütersloh.
Mourgen

Rosenberg, A., 2012, Philosophy of science: A contemporary introduction, 3rd edn., Routledge, New York.

Van Niekerk, A.A., 2011, 'Understanding theology as understanding', Acta Theologica Supplementum 14, 110-124. 